ESRI

SURVEY AND

STATISTICAL

REPORT SERIES

NUMBER 106

MAY 2021

SCOPING PAPERS FOR RESEARCH ON

THEECONOMIC AND SOCIAL

OPPORTUNITIES FROM INCREASED

COOPERATION ON THE SHARED ISLAND'

ADELE BERGIN, AOIFE BRICK, SHEELAH CONNOLLY, MARTINA LAWLESS, SEAMUS MCGUINNESS, CIARÁN O'NEILL, IULIA SIEDSCHLAG, EMER SMYTH AND MAEV-ANN WREN

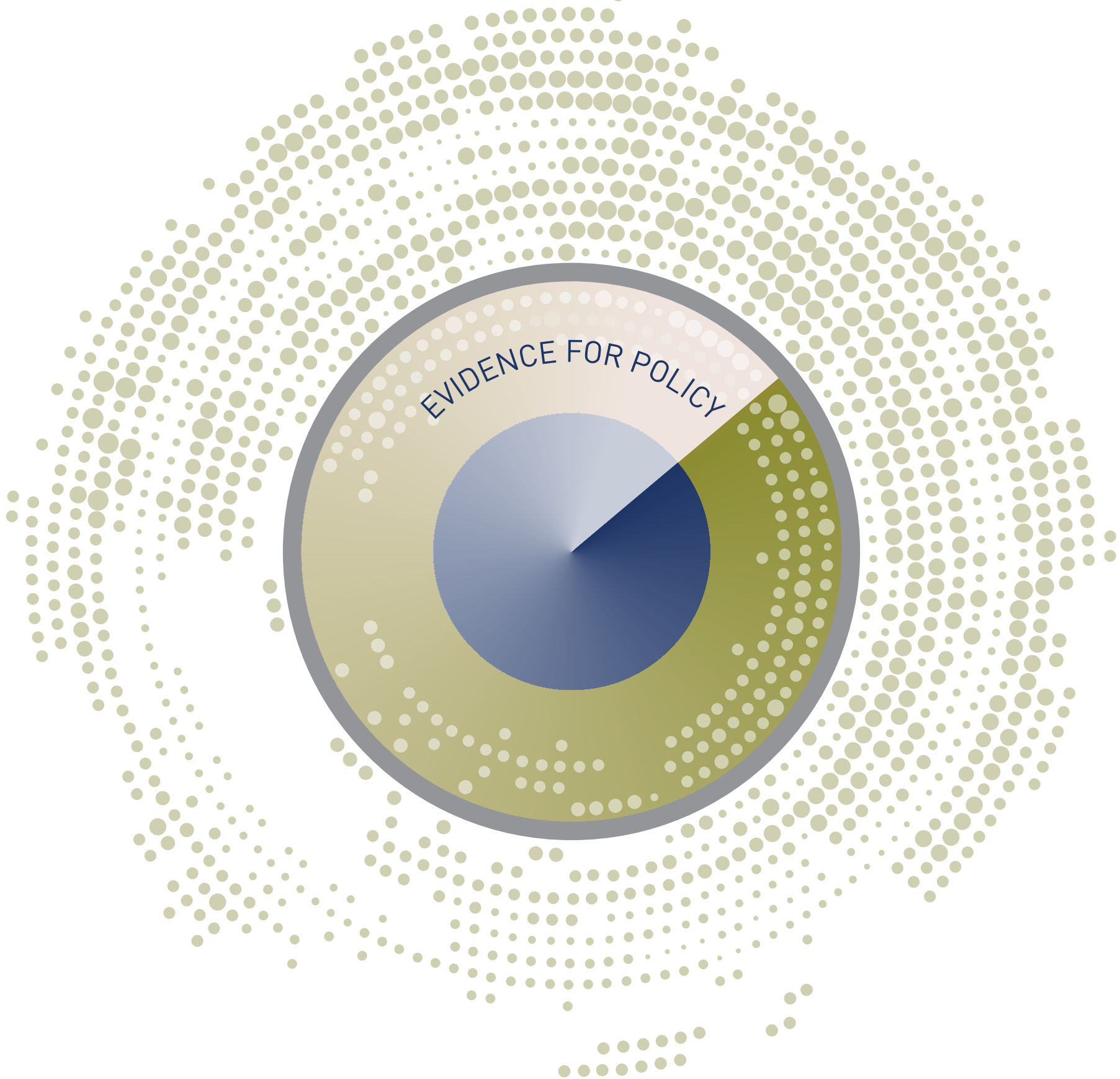

- 


\section{SCOPING PAPERS FOR RESEARCH ON 'THE ECONOMIC AND SOCIAL OPPORTUNITIES FROM INCREASED COOPERATION ON THE SHARED ISLAND'}

Adele Bergin, Aoife Brick, Sheelah Connolly, Martina Lawless, Seamus

McGuinness, Ciarán O’Neill, lulia Siedschlag, Emer Smyth and Maev-Ann Wren

May 2021

\section{ESRI SURVEY AND STATISTICAL REPORT SERIES}

\section{NUMBER 106}

Available to download from www.esri.ie

(C) The Economic and Social Research Institute

Whitaker Square, Sir John Rogerson's Quay, Dublin 2

https://doi.org/10.26504/sustat106

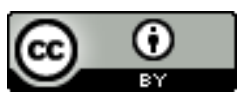

This Open Access work is licensed under a Creative Commons Attribution 4.0 International License (https://creativecommons.org/licenses/by/4.0/), which permits unrestricted use, distribution, and reproduction in any medium, provided the original work is properly credited. 


\section{ABOUT THE ESRI}

The mission of the Economic and Social Research Institute is to advance evidencebased policymaking that supports economic sustainability and social progress in Ireland. ESRI researchers apply the highest standards of academic excellence to challenges facing policymakers, focusing on 12 areas of critical importance to 21st Century Ireland.

The Institute was founded in 1960 by a group of senior civil servants led by $\mathrm{Dr}$ T. K. Whitaker, who identified the need for independent and in-depth research analysis to provide a robust evidence base for policymaking in Ireland.

Since then, the Institute has remained committed to independent research and its work is free of any expressed ideology or political position. The Institute publishes all research reaching the appropriate academic standard, irrespective of its findings or who funds the research.

The quality of its research output is guaranteed by a rigorous peer review process. ESRI researchers are experts in their fields and are committed to producing work that meets the highest academic standards and practices.

The work of the Institute is disseminated widely in books, journal articles and reports. ESRI publications are available to download, free of charge, from its website. Additionally, ESRI staff communicate research findings at regular conferences and seminars.

The ESRI is a company limited by guarantee, answerable to its members and governed by a Council, comprising 14 members who represent a cross-section of ESRI members from academia, civil services, state agencies, businesses and civil society. The Institute receives an annual grant-in-aid from the Department of Public Expenditure and Reform to support the scientific and public interest elements of the Institute's activities; the grant accounted for an average of 30 per cent of the Institute's income over the lifetime of the last Research Strategy. The remaining funding comes from research programmes supported by government departments and agencies, public bodies and competitive research programmes.

Further information is available at www.esri.ie 


\section{THE AUTHORS}

Martina Lawless is a Research Professor at the Economic and Social Research Institute (ESRI) and an Adjunct Professor at Trinity College Dublin (TCD).

Sheelah Connolly is a Senior Research Officer at the Economic and Social Research Institute (ESRI) and an Adjunct Associate Professor at Trinity College Dublin (TCD). Maev-Ann Wren is a Senior Research Office at the ESRI and an Adjunct Associate Professor at TCD. Aoife Brick is a Research Officer at the ESRI and an Adjunct Assistant Professor at TCD. Ciaran O'Neill is a Professor at the School of Medicine, Dentistry and Biomedical Sciences at Queens University Belfast.

Emer Smyth is a Research Professor at the Economic and Social Research Institute (ESRI) and an Adjunct Professor at Trinity College Dublin (TCD). Adele Bergin is an Associate Research Professor at the Economic and Social Research Institute (ESRI) and an Adjunct Professor at Trinity College Dublin (TCD). Seamus McGuinness is a Research Professor at the Economic and Social Research Institute (ESRI) and an Adjunct Professor at Trinity College Dublin (TCD).

Iulia Siedschlag is an Associate Research Professor at the Economic and Social Research Institute (ESRI) and an Adjunct Professor at Trinity College Dublin (TCD).

\section{ACKNOWLEDGEMENTS}

This research forms part of a research partnership between the ESRI and the Shared Island unit of the Department of the Taoiseach on 'The Economic and Social Opportunities from Increased Cooperation on the Shared Island'. The purpose of the programme is to produce research outputs which will add to understanding of current and potential linkages across the island of Ireland in a range of economic, social and environmental domains. Research outputs will be published through 2021 and subsequent years. Scoping papers on each of the outputs are being published to set out the terms of reference for the research work this year.

The authors would like to thank the Shared Island Unit of the Department of the Taoiseach and the members of the research programme steering committee as well as Kerry Curran and Nola Hewitt-Dundas for useful discussions on the planned research. 



\section{TABLE OF CONTENTS}

FOREWORD

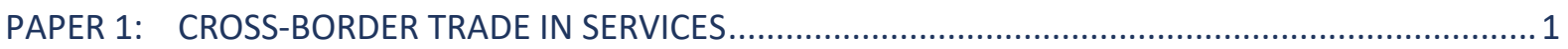

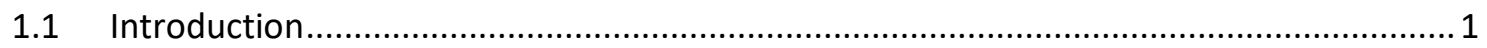

1.2 Context: Patterns of trade in services ..................................................................... 2

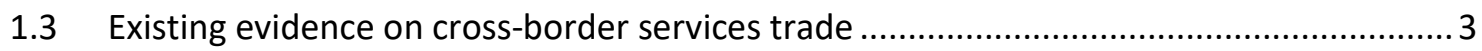

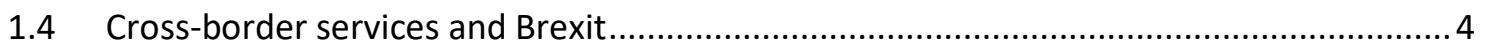

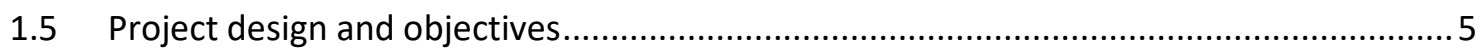

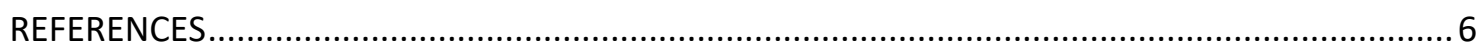

PAPER 2: PRIMARY CARE - IRELAND AND NORTHERN IRELAND ….................................................. 7

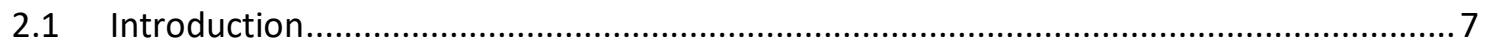

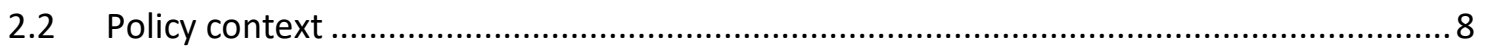

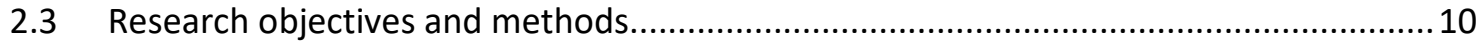

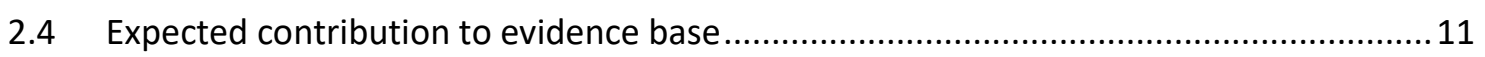

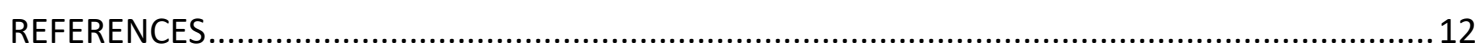

PAPER 3: A NORTH-SOUTH COMPARISON OF EDUCATION AND TRAINING SYSTEMS: LESSONS FOR

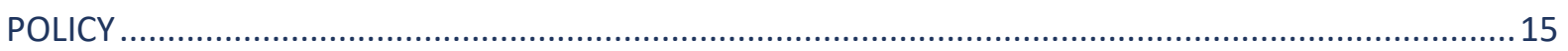

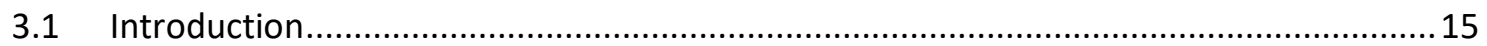

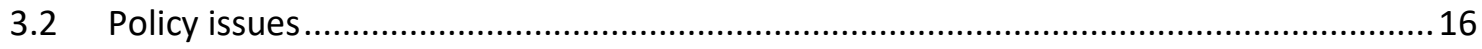

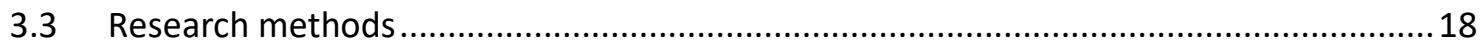

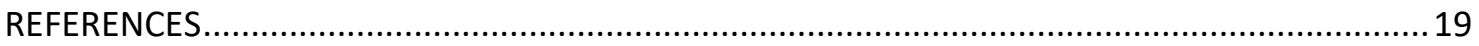

PAPER 4: ENHANCING THE ATTRACTIVENESS OF THE ISLAND OF IRELAND TO HIGH-VALUE FOREIGN

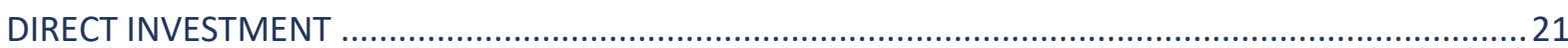

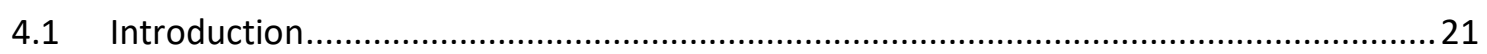

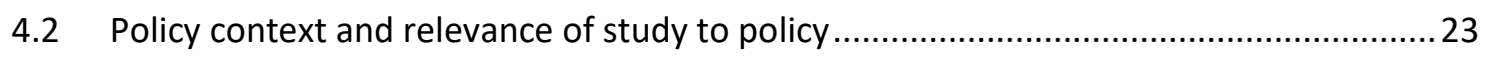

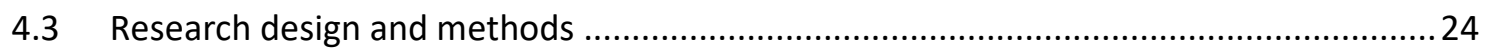

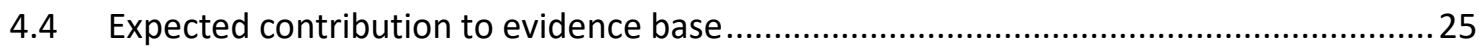

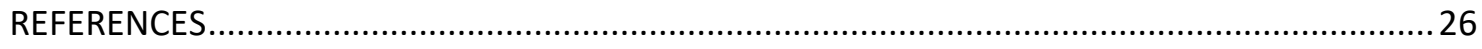





\section{FOREWORD}

\section{Anne Barrington}

I am very glad to chair the joint research programme of the Department of the Taoiseach and the Economic and Social Research Institute (ESRI) on 'Economic and Social Opportunities from Increased Cooperation on the Shared Island.'

As a former Joint Secretary of the North South Ministerial Council and Ambassador and diplomatic representative for Ireland abroad, I saw at first hand the considerable practical benefits that North-South cooperation delivers for people across the island, as an integral part of the Good Friday Agreement. From improved access to local and specialist health services, to effective marketing abroad of the world-class tourism offering on the island, to integrated supports for SMEs to grow their business across the border - cooperation contributes to wellbeing, prosperity and effective governance on the island of Ireland, and enhances how we can relate to and understand each other, across communities and political traditions, North and South.

In my experience, increased cooperation on the island is most effectively pursued through inclusive engagement and consensus-building with all stakeholders - an exercise that is greatly assisted with robust data and evidence, and rigorous, non-partisan analysis on needs, opportunities, benefits and costs.

Today, key aspects of the Irish Government's Shared Island initiative include working with the Northern Ireland Executive and the British Government to address strategic challenges faced on the island and working to enhance all aspects of North-South cooperation and the all-island economy.

In support of these objectives, the joint research programme between the ESRI and the Shared Island unit in the Department of the Taoiseach will produce research outputs that add to understanding of current and potential linkages across the island of Ireland in a range of economic, social and environmental domains. The research programme in 2021 is examining key aspects of health, education and enterprise, as well as trade in services on the island.

This report brings together scoping papers for each research project being conducted under the programme this year. These scoping papers set out the focus for this research work; key questions, issues and knowledge gaps; the policy context, North and South; and the research design and methods. The scoping 
papers are intended to support understanding of and engagement with the joint research programme as it proceeds.

I look forward to seeing research work completed and published under the joint programme in 2021 and subsequent years, contributing new knowledge and analysis on how we share the island today in key areas, and informing public and political discourse on the opportunities of increased cooperation in the years ahead, underpinned by the Good Friday Agreement.

Anne Barrington, Chair, Joint Research Programme Steering Committee; Former Ambassador and Special Envoy of the Government of Ireland

[Responses to the scoping papers can be provided to sharedisland@taoiseach.gov.ie] 


\section{PAPER 1: CROSS-BORDER TRADE IN SERVICES}

\section{Martina Lawless}

Research on 'Cross-Border Trade in Services' will be conducted over the period April-July and the report will be published after peer-review.

\section{$1.1 \quad$ INTRODUCTION}

Amongst the core objectives of the Shared Island initiative launched by the Irish Government in October 2020 is the enhanced development of the all-island economy. ${ }^{1}$ The importance of the existing levels of economic connection, particularly in the border counties, between Ireland and Northern Ireland was brought into the spotlight in recent years when the uncertainty surrounding Brexit negotiations looked liable to disrupt these flows. With the conclusion of the Brexit process, promoting economic growth and increased linkages across the island has moved to being a policy priority that has many different facets across sectors, enterprise polices as well as investment decisions by both the public and private sector.

To support this objective, this project will focus on building understanding of the structure and composition of cross-border trade in services on the island of Ireland. As exporting is a key driver of overall economic growth, information on export participation, structure and performance is a necessary input into providing a supportive policy environment for firms. Although services make up a substantial and growing portion of economic activities in both Ireland and Northern Ireland, data limitations have resulted in this sector being less thoroughly investigated than manufacturing and goods trade.

In addition to the importance of services in overall economic activity across the island, cross-border services trade potentially remains exposed to post-Brexit changes in market access between the UK and EU. The Northern Ireland Protocol to the UK's Withdrawal Agreement from the EU enables open goods trade from Northern Ireland to the rest of the UK market and across the EU Single Market. However, the Protocol does not apply to trade in services. Continuing market access in some services will rely on unilateral decisions made by the EU and UK, for example decisions on 'equivalence' for financial services or rules regarding data transfer which could have implications for cross-border services flows. 
In this context, this project aims to fill as far as possible the knowledge gap on the structure and composition of cross-border trade in services. This will be undertaken with a thorough assessment of all available data to develop a detailed profile of the sector across service types and firm characteristics. This profile can then be used in the future to assess impacts of any changes in services trade requirements post-Brexit and to explore areas where there is potential for crossborder synergies to be further developed. It will also help to identify where gaps remain in the data infrastructure. This scoping paper provides some context for the project, including key features of the measurement and operation of services activities that necessitate them being examined separately from goods trade.

\subsection{CONTEXT: PATTERNS OF TRADE IN SERVICES}

International trade in services has been growing strongly for many years at a global level, with average annual growth rates of over 5 per cent between 2005 and 2017. Services are estimated by the World Trade Organisation (2019) to account for almost half of international trade when all modes of delivery are measured. Despite this steady expansion over recent decades, substantially less is known about services trade flows and the activities of firms exporting services relative to the wealth of information available on goods exports.

Much of the reason for this evidence gap comes from the degree of difficulty in measuring services trade flows. There are several different modes of delivery to be considered as well as the intangible nature of many services making categorisation more challenging than for products. The General Agreement on Trade in Services (GATS) describes four modes through which services may be traded:

- Mode 1: Cross-border supply - the supplier in one country delivers a service to a customer in another country remotely (e.g. via e-mail, telephone) without either supplier or customer moving location.

- Mode 2: Consumption abroad - the customer travels to the country where the supplier is located to avail of the service (e.g. tourism exports).

- Mode 3: Commercial presence - firms supply services in another country through the presence of an affiliate in that country (this mode is not included as cross-border trade in official statistics).

- Mode 4: Presence of natural persons - the supplier travels to the country in which the customer is located to supply the service (e.g. business consultancy).

Evidence on firm participation in international trade has consistently found that it is much rarer for a services firm to export than for a manufacturing firm, indicating greater costs or barriers to exporting services compared to goods exporting (see 
for example Ariu, 2016). Some of this difference can be attributed to the nontradable nature of some types of services. The expansion of international trade in services shows that this is not the case for all aspects of services, and examining how cross-border flows compare to other directions of services trade should give insight into possible growth areas.

Some systematic patterns in relation to firm export participation have been found to apply in both services and manufacturing. In general, research such as Damijan et al. (2015) comparing firms in Finland, France, Ireland and Slovenia shows that exporters are larger, more productive and pay higher wages than non-exporters. Service exports and imports have also been found to be highly concentrated among a relatively small proportion of firms. Previous work on the export composition of firms in Ireland points out that that firms exporting in the services sector frequently export a mix of goods and services, so it is important to consider complementarities between different activities at the firm level when examining the determinants of types of export flows (Lawless and Studnicka, 2017).

\subsection{EXISTING EVIDENCE ON CROSS-BORDER SERVICES TRADE}

Comparisons of the broad economic structure in Ireland and Northern Ireland show that output is more goods-orientated in Northern Ireland relative to Ireland where the output shares of goods and services are almost equal (InterTradelreland, 2018a). In Northern Ireland, goods output accounts for over 70 per cent of total turnover with the remaining 30 per cent in services. Output in Ireland has a services sector share of around 46 per cent, including the activities of multinational exporters. In addition, the services sector has a much greater export orientation in Ireland compared to that of services in Northern Ireland, with multinational activity playing a central role in the difference between the two economies. The services sector in Ireland exports 62 per cent of its output and services account for slightly over half of total exports. In Northern Ireland, on the other hand, just over a quarter of services output is sold externally (i.e. including sales to Great Britain as well as exports).

Research on cross-border trade activity by InterTradelreland (2018a) found that almost all exporting firms in Northern Ireland included Ireland as one of their destination markets. Over 80 per cent of exporters amongst small firms in Northern Ireland had all their export sales in Ireland and close to half of large exporters also sold only into Ireland.

Comparison of productivity distributions for firms in Ireland and Northern Ireland found that services firms in both areas were typically less productive than goods firms overall. However, a substantial export premium was observed with services exporters (which in Northern Ireland was defined to include firms with external 
sales to Great Britain) having higher productivity relative to firms with all their sales in the local market. This gap between exporters and non-exporters was also found for goods firms but was more marked for services firms (InterTradelreland, 2018b).

This well-documented link between exporting activity and greater firm productivity provides a rationale for providing policy support to firms to enter exporting. Policy interventions are particularly relevant for the initial entry of firms to exporting activity as this appears to be the most difficult hurdle for firms to cross. For most firms, the first export market entered will be the closest, where there is high familiarity and low costs to entry. For many firms, this may remain the sole export market. However, if exporting in the first market is successful, firms grow their exports as much by expanding into other markets as by growing sales in existing markets.

Lawless (2013) found that exporting experience for firms in Ireland to geographically nearby markets increased the probability of entry into additional markets and reduced the probability of exit significantly. Total exports of other Irish firms in each market also promoted entry, providing evidence of a strong demonstration effect or information spillovers from other exporters. In the context of cross-border trade, this suggests that building experience in this arena could act as a 'stepping stone' for firms in both Ireland and Northern Ireland towards broader external sales activity, leading to wider growth opportunities.

\subsection{CROSS-BORDER SERVICES AND BREXIT}

The EU-UK Trade and Cooperation Agreement signed in December 2020 and the specific provisions in the Northern Ireland Protocol to the earlier Withdrawal Agreement both provide for facilitating goods trade and have limited application to services. Market access in services between the EU and UK has remained relatively unchanged due to a range of temporary recognition arrangements but this is an area where restrictions are still a possibility in the near term. The Protocol also provides that Northern Ireland operates within the EU VAT area for goods but not for services. This means some changes to how VAT is charged on services for cross-border trade, depending on whether the purchaser is a business or a consumer (Revenue Commissioners, 2020).

Research by Shepard (2019) estimated how costly potential restrictions on services trade post-Brexit would be for Northern Ireland, including a scenario similar to the agreed post-Brexit trading arrangements. This found considerable variation in the degree to which different parts of the services sector might be affected by a range of restrictions. Courier services and professional services such as accountancy and legal services were amongst the most exposed to changes in market access regulations. 
The continuation of the Common Travel Area means that many important underpinnings of services trade remain in place between the UK - including Northern Ireland - and Ireland. The estimates for the impact of any new restrictions on services trade was therefore found to be lower for trade between Northern Ireland and Ireland relative to potential impacts on Northern Ireland's trade with the rest of the EU.

\subsection{PROJECT DESIGN AND OBJECTIVES}

This note has summarised some of the international findings that motivate the next steps of this research project. These include the substantial and growing role of services in modern economies and international trade, links at the firm level between exporting activity and productivity and the challenges posed by the intangible nature of many services for firm export participation. Verifying these international patterns, the existing evidence on trade in services for Ireland and Northern Ireland has found significant links between exporting and firm performance.

Compared to the depth of information and analysis undertaken on the export patterns of goods trade, there are several gaps in our knowledge base on the extent and composition of cross-border services trade. The aim of this research project is to undertake a comprehensive stocktake of available data and to build a detailed profile of cross-border services. This will draw together information on the types of services traded and the associated firm characteristics where available. This profile can then be utilised as a benchmark against which the impact of any further changes in services trade requirements post-Brexit can be assessed on an ongoing basis. This profile may also assist in future work to identify areas where there is potential for cross-border synergies in services trade and promotion. The data stocktake should also be helpful in highlighting precisely where information gaps occur and can be filled most effectively. 


\section{REFERENCES}

Ariu, A. (2016). 'Services versus goods trade: a firm level comparison?', Review of World Economics, Vol. 152, pp. 19-41.

Damijan, J., S.A. Haller, V. Kaitila, Č. Kostevc, M. Maliranta, E. Milet, D. Mirza and M. Rojec (2015). 'The performance of trading firms in the services sectors Comparable evidence from four EU countries', The World Economy, 38(12), pp. 1809-1849.

InterTradelreland (2018a). 'Export Participation and Performance of Firms on the Island of Ireland', https://intertradeireland.com/news/export-participation-andperformance-of-firms-on-the-island-of-ireland/.

InterTradelreland (2018b). 'Shock Absorption Capacity of Firms in Ireland and Northern Ireland', https://intertradeireland.com/insights/publications/shock-absorptioncapacity-of-firms-in-ireland-and-northern-ireland/008906-iti-capacity-reportweb-ready/.

Lawless, M. (2013). 'Marginal Distance: Does Export Experience Reduce Firm Trade Costs?', Open Economies Review, Vol.24, No.5, pp. 819-841.

Lawless, M. and Z. Studnicka (2017). Services Exports and Exporters of Services, joint report published by ESRI, Department of Jobs, Enterprise and Innovation and Enterprise Ireland.

Revenue Commissioners (2020). 'VAT - Trade between Ireland and Northern Ireland', https://www.revenue.ie/en/customs-traders-and-agents/brexit/informationfor-businesses-trading-with-ni/vat-trade-with-ni-after-transition/trade-inservices-with-northern-ireland.aspx.

Shepard, B. (2019). 'EU Exit and Impacts on Northern Ireland's Services Trade', https://www.economy-ni.gov.uk/publications/eu-exit-and-impacts-northernirelands-services-trade.

World Trade Organization (2019). 'World Trade Report: The future of services trade', https://www.wto.org/english/res_e/booksp_e/00_wtr19_e.pdf. 


\section{PAPER 2: PRIMARY CARE - IRELAND AND NORTHERN IRELAND}

\section{Sheelah Connolly, Maev-Ann Wren, Aoife Brick and Ciarán O’Neill}

Research on 'Primary care - Ireland and Northern Ireland' will be conducted over the period AprilNovember and the report will be published after peer-review.

\section{$2.1 \quad$ INTRODUCTION}

The area of health has been identified as a key area offering potential for greater cooperation for Ireland and Northern Ireland and is a focus for the Shared Island initiative. There have been important North-South cooperation initiatives in border regions and in specific areas of service provision (including transplant services and paediatric cardiac services); however, overall cooperation across the two sectors has been seen as limited (Heenan, 2021). Considerations on where increasing cooperation can best be pursued can benefit from a better understanding of how population health might differ between Ireland and Northern Ireland as well as detailed information on the similarities and differences between the two health systems.

This chapter details a research project comparing the primary care systems of Ireland and Northern Ireland that will be undertaken in 2021. The remainder of this section briefly describes potential areas for further research in an Ireland/Northern Ireland context (including the potential benefits of increased cooperation and differences in health status and health systems). The remaining sections provide additional detail on the project on primary care which will explore the similarities and differences between the primary care systems of Ireland and Northern Ireland to identify learnings for policy reform processes in this area in either jurisdiction.

\subsubsection{Potential benefits of increased cooperation in healthcare delivery}

While there have been some examples of cooperation in health services between Ireland and Northern Ireland (Pollak, 2019), closer cooperation in a range of areas could deliver economies of scale, value for money, opportunities for clinical specialisation and the sharing of knowledge and good practice (Heenan, 2021). Increasing pressure on both health systems arising in part from changing population size and structure may provide a fresh impetus for increased cooperation. Reaching agreement on increased cooperation will depend on political and other factors but can be assisted by additional information on the potential benefits of such cooperation. This includes the potential for the abovementioned economies of scale, in addition to improved health outcomes and greater access to healthcare. Currently such analysis is limited, in part due to a lack of comparable data across the jurisdictions. 


\subsubsection{Differences in health status}

Previous research has highlighted differences in overall population health measures for Ireland and Northern Ireland. For example, Bergin and McGuinness (2021) recently noted that life expectancy in Northern Ireland exceeded that in Ireland up to 2005. However, in the following years, continued stronger improvements in life expectancy in Ireland meant that it surpassed Northern Ireland, and that the gap between the two regions has been increasing in more recent years. Given the wide-ranging factors which influence life expectancy (including income, education, healthcare, lifestyle and environmental factors) it is difficult to explain the observed differences, though doing so could provide valuable clues about how to improve population health.

Detailed information on differences in health status between Ireland and Northern Ireland - for example, on the prevalence of chronic diseases, mental health issues and behavioural risk factors - would provide valuable insights into the potential causes of differences in health status between the two jurisdictions. In the context of the island of Ireland, the feasibility of such an analysis is assisted by the growing number of comparable datasets in the two jurisdictions including Growing Up in Ireland (Ireland) and the Millennium Cohort Study for children and young people (England, Scotland, Wales and Northern Ireland) as well as The Irish Longitudinal Study on Ageing (TILDA) and the Northern Ireland Cohort for the Longitudinal Study of Ageing (NICOLA) for people aged 50 and over.

\subsubsection{Differences in health systems}

Recent reform proposals from both Ireland (the Sláintecare Report) (Houses of the Oireachtas Committee on the Future of Healthcare, 2017) and Northern Ireland (the Bengoa report) (Bengoa et al., 2016) have emphasised the need for health system reform which refocuses healthcare away from the hospital sector towards the delivery of more care in the community. While there are similarities between the health systems of Ireland and Northern Ireland (for example, both are predominantly tax financed and the General Practitioner (GP) plays a key gatekeeping role in both systems); differences between the two systems, in particular in relation to eligibility for primary care services, provide an opportunity to explore how these differences might impact on a range of factors including healthcare utilisation, unmet healthcare needs and healthcare expenditure.

\subsection{POLICY CONTEXT}

Previous research has shown that a strong primary care system can contribute to the overall performance of the healthcare system (Starfield, 1994; Delnoij et al., 2000; Macinko et al., 2003; Shi et al., 2005). Kringos et al. (2013), for example, found that while strong primary care was associated with higher levels of healthcare spending, it was also associated with a reduced rate of growth in 
healthcare spending; lower rates of potentially avoidable hospitalisation; better population health outcomes; and lower socioeconomic inequality in self-rated health. Healthcare systems across Europe are experiencing a number of challenges including financial constraints, increasing demand, workforce developments and growing possibilities of technology (Kringos et al., 2015). For many countries, including Ireland and Northern Ireland, addressing these challenges has included attempts at strengthening primary care.

While a number of features contribute to creating a strong primary care system including comprehensiveness and continuity of care as well as efficiency and equity - a key component is accessibility, which incorporates issues of availability, affordability and acceptability (Kringos et al., 2010). Previous research from Europe has found that countries with better access to primary care had lower rates of potentially avoidable hospitalisations for diabetes (Kringos et al., 2013), while a growing body of American literature has shown a positive association between accessibility of primary care and population health (Starfield et al., 2005; Friedberg et al., 2007).

With regard to access to primary care, both Ireland and Northern Ireland perform relatively poorly. High out-of-pocket payments in Ireland act as a barrier to accessing primary care services for some people, with a previous study finding that in Ireland 19 per cent of patients had a medical problem in the previous year but had not consulted the doctor because of cost, compared to less than 2 per cent of patients in Northern Ireland (O'Reilly et al., 2007). While there are no financial barriers to accessing primary care services in Northern Ireland, in recent years demand for such services has outstripped supply, with the result that many people experience long waits to access such services (McGuinness and Bergin, 2020). In both systems there are long waits for hospital-based services (Appleby, 2019; Brick and Connolly, 2021).

Recognising these and other challenges to the healthcare system, both the Sláintecare Report and the Bengoa report have highlighted the need for health system reform which reorientates the health system towards increased delivery of healthcare in the community (Bengoa et al., 2016; Houses of the Oireachtas Committee on the Future of Healthcare, 2017). The Sláintecare Report, for example, recommended (among other things) the introduction of universal GP and primary care, reducing or removing out-of-pocket fees and substantially increasing public healthcare expenditure and capacity in a tax-funded system. In Northern Ireland, the Bengoa report noted the need for an integrated primary and community health and social care delivery model so that more can be done out of hospitals. A commission on the future of the National Health Service in the UK recently highlighted the importance of adequate funding and workforce planning for primary care to ensure the long-term future of the NHS (Anderson et al., 2021). 


\subsection{RESEARCH OBJECTIVES AND METHODS}

The aim of the research detailed in this proposal is to compare the primary care systems in Ireland and Northern Ireland to identify if there are learnings for both jurisdictions to inform the processes on reform of primary care.

The research project has four main objectives:

1. To compare the primary care systems of Ireland and Northern Ireland along a number of domains including eligibility, structure, workforce, financing and expenditure.

2. To quantify a range of primary care metrics in both jurisdictions including outof-pocket expenditure, visiting rates, unmet healthcare needs and uptake of preventive services.

3. To examine how differences in primary care systems in Ireland and Northern Ireland might impact on other parts of the system including the hospital sector.

4. To draw out implications for policy.

The first phase of this analysis will comprise a literature review including national and international literature and government documents. This will identify similarities and differences between the primary care systems of Ireland and Northern Ireland along a number of domains including eligibility, reimbursement of providers, workforce and workforce practices, financing and expenditure. Contact will be made with relevant healthcare professionals and officials in both jurisdictions if clarity is required on aspects of the operation of the primary care systems.

Secondly, a range of relevant primary care metrics will be identified and quantified including out-of-pocket expenditure, visiting rates and uptake of preventive services. Data sources will include existing literature, as well as statistical and government publications and existing administrative datasets. Existing surveys which have similar components across both jurisdictions will also be analysed where feasible. ${ }^{2}$ The analysis will also seek to identify if observed differences in the included metrics are related to the differences in the primary care systems identified in the first phase.

Thirdly, the research will examine how differences in the primary care systems might be related to utilisation and costs in the hospital sectors. The analysis will examine if avoidable hospitalisations (especially for conditions that might be more 
appropriately treated in primary care) differ across the two jurisdictions. Previous research for Ireland found that ambulatory care sensitive conditions (acute or episodic conditions where appropriate and timely community care can prevent disease and/or hospital admissions) represented almost 19 per cent of publicly funded bed days in Ireland in 2016 (McDarby and Smyth, 2019). The analysis will use data from the Hospital In-Patient Enquiry scheme for Ireland and acute hospital-based activity data for Northern Ireland to try to identify the number of avoidable hospitalisations in both jurisdictions. ${ }^{3}$ There will be a particular focus on conditions where the analysis in the first phase has highlighted differences in utilisation across the two jurisdictions.

Finally, building on the existing research which has already fed into the Sláintecare reform plan, the project will draw out implications for policy with reference to the primary care reform processes and areas of cross-learning between the two jurisdictions.

\subsection{EXPECTED CONTRIBUTION TO EVIDENCE BASE}

Differences between the primary care systems of Ireland and Northern Ireland provide an opportunity to analyse how these differences impact on a range of metrics within and beyond the primary care system. Similar types of analyses for the four regions of the United Kingdom have proved useful in identifying potential benchmarks for the health systems, identifying how different policy approaches impact on outcomes and for increasing awareness of the importance of comparable data across the systems (Bevan et al., 2014). It is anticipated that this research will provide insights about how the differences in the primary care systems influence outcomes, and in doing so can inform considerations on the reform of primary care, in Ireland and Northern Ireland, and identify areas of crosslearning. 


\section{REFERENCES}

Anderson, M., E. Pitchforth, M. Asaria, et al. (2021). 'The future of the NHS: re-laying the foundations for an equitable and efficient health and care service after COVID-19', The Lancet, https://doi.org/10.1016/ S0140-6736(21)00232-4.

Appleby, J. (2019). 'Waiting times compared across the four UK nations', British Medical Journal, Vol. 367, 16237.

Bengoa, R., A. Stout, B. Scott, M. McAlinden and M. Taylor (2016). Systems, not structures: Changing health and social care. Belfast: Expert Panel Report.

Bergin, A. and S. McGuinness (2021). 'Who is Better off? Measuring Cross-border Differences in Living Standards, Opportunities and Quality of Life on the Island of Ireland', Irish Studies in International Affairs, Vol. 32, No. 2, pp. 143-160.

Bevan, G., M. Karanikolos, J. Exley, E. Nolte, S. Connolly and N. Mays (2014). The four health systems of the United Kingdom: How do they compare? London, United Kingdom: The Health Foundation, The Nuffield Trust.

Brick, A. and S. Connolly (2021). 'Waiting Times for Publicly Funded Hospital Treatment: How does Ireland Measure Up?', The Economic and Social Review, Vol. 52, No. 1, pp. 41-52.

Delnoij, D., G. Van Merode, A. Paulus and P. Groenewegen (2000). 'Does general practitioner gatekeeping curb health care expenditure?', Journal of Health Services Research and Policy, Vol. 5, No. 1, pp. 22-26.

Friedberg, M.W., K.L. Coltin, S.D. Pearson, K.P. Kleinman, J. Zheng, J.A. Singer and E.C. Schneider (2007). 'Does affiliation of physician groups with one another produce higher quality primary care?', Journal of General Internal Medicine, Vol. 22, No. 10 , pp. $1385-1392$.

Heenan, D. (2021). 'Cross-Border Cooperation Health in Ireland', Irish Studies in International Affairs, Vol. 32, No. 2, pp. 117-136.

Houses of the Oireachtas Committee on the Future of Healthcare (2017). Sláintecare Report. Dublin, Ireland: Houses of the Oireachtas.

Kringos, D.S., W.G. Boerma, Y. Bourgueil, T. Cartier, T. Hasvold, A. Hutchinson, M. Lember, M. Oleszczyk, D.R. Pavlic, I. Svab, P. Tedeschi, A. Wilson, A. Windak, T. Dedeu and S. Wilm (2010). 'The European primary care monitor: structure, process and outcome indicators', BMC Family Practice, Vol. 11, p. 81.

Kringos, D.S., W. Boerma, J. van der Zee and P. Groenewegen (2013). 'Europe's strong primary care systems are linked to better population health but also to higher health spending', Health Affairs, Vol. 32, No. 4, pp. 686-694.

Kringos, D., W. Boerma, A. Hutchinson and R. Saltman (2015). Building primary care in a changing Europe. Copenhagen: European Observatory on Health Systems and Policies.

Macinko, J., B. Starfield and L. Shi (2003). 'The contribution of primary care systems to health outcomes within Organization for Economic Cooperation and Development (OECD) countries, 1970-1998', Health Services Research, Vol. 38, No. 3, pp. 831-865. 
McDarby, G. and B. Smyth (2019). 'Identifying priorities for primary care investment in Ireland through a population-based analysis of avoidable hospital admissions for ambulatory care sensitive conditions (ACSC)', BMJ Open, Vol. 9, No. 11, e028744.

McGuinness, S. and A. Bergin (2020). 'The political economy of a Northern Ireland border poll', Cambridge Journal of Economics, Vol. 44, No. 4, pp. 781-812.

O’Reilly, D., T. O’Dowd, K.J. Galway, A.W. Murphy, C. O'Neill, E. Shryane, K. Steele, G. Bury, A. Gilliland and A. Kelly (2007). 'Consultation charges in Ireland deter a large proportion of patients from seeing the GP: results of a cross-sectional survey', European Journal of General Practice, Vol. 13, No. 4, pp. 231-236.

Pollak, A. (2019). 'Whatever happened to north-south co-operation?', Belfast Telegraph, 1 February 2019. https://www.belfasttelegraph.co.uk/opinion/newsanalysis/andy-pollak-whatever-happened-to-north-south-co-operation37771538.html.

Shi, L., J. Macinko, B. Starfield, R. Politzer, J. Wulu and J. Xu (2005). 'Primary care, social inequalities, and all-cause, heart disease, and cancer mortality in US counties, 1990', American Journal of Public Health, Vol. 95, No. 4, pp. 674-680.

Starfield, B. (1994). 'Is primary care essential?', Lancet, Vol. 344, No. 8930, pp. 1129-1133.

Starfield, B., L. Shi and J. Macinko (2005). 'Contribution of primary care to health systems and health,' Milbank Quarterly, Vol. 83, No. 3, pp. 457-502. 



\section{PAPER 3: A NORTH-SOUTH COMPARISON OF EDUCATION AND TRAINING SYSTEMS: LESSONS FOR POLICY}

\section{Emer Smyth, Adele Bergin and Seamus McGuinness}

Research on 'A North-South comparison of education and training systems: lessons for policy' will be conducted over the period April-November and the report will be published after peer-review.

\subsection{INTRODUCTION}

A key focus of the Shared Island initiative is to deepen cooperation in areas like health and education. Given the difference in education and training, North and South, it is remarkable that there has been so little research comparing the systems. This study aims to fill the gap by comparing the two systems as a basis for policy learning. Policy learning allows us to reflect on one system through the lens of another, identifying options for the future and recognising challenges that may arise, rather than attempting to 'transplant' aspects of a system to a very different context (Raffe and Semple, 2011).

The skills people acquire and the qualifications they attain have far-reaching consequences at the individual level, influencing their access to employment, the quality of that employment, career progression, wage growth, and their broader life chances (such as health and wellbeing). How well an education and training system facilitates the acquisition of skills and qualifications matters not only for individuals but for broader society. Early school leaving incurs significant societal costs in terms of lower tax revenues, higher dependency on welfare payments and higher expenditure on services such as health and criminal justice. At the other end of the spectrum, high rates of third-level attainment can be an important factor in attracting more foreign direct investment, which can boost employment, productivity, economic growth and tax revenues. Understanding the way the education/training system shapes pathways to qualifications is therefore crucial.

A broad comparison between the two jurisdictions shows that, among both younger age-groups and the working-age population as a whole, rates of school leaving after the end of lower secondary education are higher in Northern Ireland while the acquisition of post-secondary qualifications is lower (McGuinness and Bergin, 2020). Furthermore, Bergin and McGuinness (2021) found that early school leaving in Northern Ireland was almost double that of Ireland; the risk of early school leaving was found to be much higher among children from working-class backgrounds and boys in Northern Ireland. But these comparisons do not tell us why the patterns arise or what groups (in terms of gender and social background) have particular types of qualifications. 
This study will provide new insights into the way in which the education and training systems, North and South, shape these outcomes, addressing the following research questions:

1. What are the patterns of educational participation and attainment in the two jurisdictions? Do patterns of educational inequality (by gender and social background) differ? ${ }^{4}$

2. What are the levels of skills among the population from primary education to adult life? Is any mismatch evident between skills and qualifications?

3. What aspects of the education/training system factors shape any differences found in skills and qualifications? What lessons can be learned for the future?

\subsection{POLICY ISSUES}

\subsubsection{Participation in early years provision}

The two systems differ in the timing and nature of early years provision. This is likely to have significant implications for the skills that children already have on starting primary education. The study will highlight potential differences in participation in early years settings and their likely consequences as a foundation for engagement with primary schooling.

\subsubsection{School choice and selection}

In Northern Ireland, the distinction between grammar and secondary schools has significant consequences for the qualifications taken by young people and their pathways after leaving school (Gallagher and Smith, 2000). The skills measured in assessments towards the end of primary education therefore matter a good deal for later life chances. Furthermore, the fact that preparations for the transfer exams are not undertaken in most primary schools means that children from more advantaged families who can afford private tuition are likely to have enhanced access to grammar schools. In Ireland, there are three types of secondary school (voluntary secondary, Education and Training Board, and community/ comprehensive), though all operate within the same curriculum and qualifications framework. Schools are not allowed to assess students for the purposes of enrolment. However, it is very common for young people to attend a school outside their local area, with around half doing so, and the families that make more proactive choices tend to be more advantaged. Both systems therefore have a degree of school segregation by social background and prior achievement/ability (and, indeed, gender, because of the persistence of single-sex schools). International research points to worse educational outcomes for young people who attend schools with a concentration of socio-economic disadvantage in the student population (see, for example, Willms, 2010). The study will therefore 
examine the consequences of these segregation processes for educational outcomes in the two jurisdictions.

\subsubsection{Mismatch between skills and qualifications}

Qualifications are taken by employers as an indicator of skills in making decisions around recruitment. However, research points to a mismatch between required skills and qualifications in some instances. An education system may be successful in producing the literacy, numeracy and digital skills needed to cope with a changing labour market but may have lower participation in tertiary education, for example. At primary level, students in Northern Ireland perform better in mathematics and around the same in reading as students in Ireland (Sturman et al., 2012); yet differences in the proportion staying on after lower secondary education are very striking. At the other end of the spectrum, a significant minority of those with degrees in Ireland have literacy levels no better than those who left education at an earlier stage. The study will examine the factors associated with these mismatches between skills and qualifications in the two settings, taking into account differences in the sectoral composition of the two workforces.

\subsubsection{Post-secondary qualifications}

Historically, both jurisdictions have had relatively underdeveloped vocational education and training systems, despite a long-standing industrial tradition in Northern Ireland. Despite this similarity, there are much higher numbers with a post-secondary qualification in Ireland. The study will examine the factors shaping these differences, an important policy issue given the potential for further education to be responsive to the demand for intermediate-level skills.

\subsubsection{Higher education}

The proportion of the population with a tertiary qualification is the product of a number of different processes: the numbers applying to and entering higher education; the numbers completing their degree; and the extent of outward migration among graduates. In Northern Ireland, a very significant minority around a quarter - of young people go to university in England, Scotland and Wales, with only a minority of these returning to NI after graduation. The study will assess the different factors at play in shaping the pool of graduates in the two jurisdictions.

\subsubsection{Returns to education and training}

While other factors influence educational decision-making, the potential returns in the form of access to employment and quality of that employment (in terms of pay levels) play an important role in incentivising participation in education and training. The study will examine the patterns of returns to different qualification 
levels in the two settings as a basis for identifying the relative incentives to educational participation.

\subsection{RESEARCH METHODS}

The study will adopt a mixed methods approach, combining the advantages of quantitative analyses in providing generalisable findings with qualitative techniques to yield rich insights into the factors shaping the nature of the education and training systems.

Labour Force Survey data will be used to examine the proportion and profile of those with different educational qualifications, and to analyse the returns to educational qualifications and the extent of mismatch between qualifications and skills. Available international survey data (such as PISA, TIMSS and PIRLS) will be used to analyse the skills and competencies developed by children and young people at different stages of their educational careers. The Millennium Cohort Study and the Growing Up in Ireland study will also be used to compare skills on entry to primary education. In addition, PIAAC data on the adult population will be used to examine the relationship between qualifications and skills (such as literacy, numeracy and digital skills) and the relative returns to education and skills.

These quantitative analyses will be supplemented with in-depth qualitative interviews with key policy stakeholders in both systems. These interviews will provide insights into (but not be limited to) differences around: the relative role of school choice and school selection in the attainment of qualifications; the position and profile of the further education sector; and the degree of geographic mobility among university students (and graduates). Analyses of both the quantitative and qualitative data will be presented via webinar to policy stakeholders in both jurisdictions, a process that is designed to contribute to policy learning as well as informing the implications for policy presented in the final report. This consultation is an important step in starting to build understanding, engagement and consensus around policy issues. Such an approach has previously been used successfully by this team in major research projects, on further education and training in general, as well as evaluations of Post-Leaving Certificate provision and second-chance courses for early school leavers (see McGuinness et al., 2014; 2018; Smyth et al., 2019). 


\section{REFERENCES}

Bergin, A. and S. McGuinness (2021). 'Who is Better off? Measuring Cross-border Differences in Living Standards, Opportunities and Quality of Life on the Island of Ireland', Irish Studies in International Affairs, 22(2), 143-160.

Gallagher, T. and A. Smith (2000). The Effects of the Selective System of Secondary Education in Northern Ireland. Belfast: Department of Education.

McGuinness, S., A. Bergin, E. Kelly, S. McCoy, E. Smyth, A. Whelan and J. Banks (2014). Further Education and Training in Ireland: Past, Present and Future. Dublin: ESRI.

McGuinness, S., A. Bergin, E. Kelly, S. McCoy, E. Smyth, D. Watson and A. Whelan (2018). Evaluation of PLC Programme Provision. Dublin: ESRI.

McGuinness, S. and A. Bergin (2020). 'The Political Economy of a Northern Ireland Border Poll', Cambridge Journal of Economics, 44(4), 781-812.

Raffe, D. and S. Semple (2011). Policy borrowing or policy learning?: How (not) to improve education systems. Edinburgh: Centre for Educational Sociology.

Smyth, E., J. Banks, J. O'Sullivan, S. McCoy, P. Redmond and S. McGuinness (2019). Evaluation of the National Youthreach Programme. Dublin: ESRI.

Sturman, L., L. Twist, B. Burge, J. Sizmur, S. Bartlett, R. Cook, L. Lynn and H. Weaving (2012). PIRLS and TIMSS 2011 in Northern Ireland: Reading, Mathematics and Science. Slough: NFER.

Willms, J.D. (2010). 'School composition and contextual effects on student outcomes', Teachers College Record, 112(4), 1008-1037. 



\title{
PAPER 4: ENHANCING THE ATTRACTIVENESS OF THE ISLAND OF IRELAND TO HIGH-VALUE FOREIGN DIRECT INVESTMENT
}

\section{Iulia Siedschlag}

Research on 'Enhancing the Attractiveness of the Island of Ireland to High-Value Foreign Direct Investment' will be conducted over the period April-September and the report will be published after peer-review.

\subsection{INTRODUCTION}

In the context of intensified global competition, economic growth in advanced economies has become increasingly dependent on the creation, diffusion, and absorption of knowledge. Knowledge-intensive sectors make an important contribution to innovation, productivity and export-led economic growth.

\begin{abstract}
A large international evidence has established that foreign direct investment (FDI) is associated with new technologies and management know-how which boost productivity and competitiveness in host countries. ${ }^{5}$ In addition, FDI projects, particularly greenfield investments, ${ }^{6}$ are linked to net job creation in host countries. ${ }^{7} \mathrm{FDI}$ has also indirect positive effects via spillovers on the productivity, ${ }^{8}$ and the trade performance of indigenous companies. ${ }^{9}$
\end{abstract}

Enhancing the attractiveness to high-value FDI is a policy objective in many regions and countries in the world as well as in Ireland and Northern Ireland. Understanding what drives the location choice of FDI in high-value knowledgeintensive sectors is important for designing such policies. To the best of our knowledge, factors underlying the attractiveness of the island of Ireland to highvalue FDI have not been examined so far.

When deciding where to invest, multinational firms consider a range of location-

5 Recent international evidence on the direct impact of FDI on productivity in host countries is discussed by, among others, Schiffbauer et al. (2017). Bloom et al. (2012) provide evidence on the role of FDI in the diffusion of frontier management practices.

$6 \quad$ New greenfield FDI projects are new operations established by foreign companies at a new site. The foreign company may or may not already be present in the country, but the FDI project is in a new location within the country. It can also include relocation from one country to another.

$7 \quad$ Siedschlag and Tong Koecklin (2019) provide evidence on the relationship between the attractiveness of EU regions to new greenfield FDI and related job creation. The results indicate that over the period 2003-2015, on average, a 1 per cent increase in the attractiveness to FDI of a representative EU region increased the corresponding FDI-related new jobs by 1.3 per cent.

8 For recent reviews of international evidence on productivity spillovers from foreign affiliates to domestic firms see for example Jude (2016) and Havranek and Irsova (2011). Recent research on productivity spillovers from multinationals on local firms on the island of Ireland include Driffield and Lavoratori (2020) for Northern Ireland, and Di Ubaldo et al., (2018) for Ireland.

$9 \quad$ For recent evidence on spillovers from multinationals on the export performance of local firms see Ciani and Imbruno (2017) and Bajgar and Javorcik (2020). Di Ubaldo and Siedschlag (2020) provide evidence on spillovers from multinationals on the export and import performance of local firms in Ireland. 
specific factors such as production costs, market size, market potential and sourcing inputs including human capital and technology. ${ }^{10}$ Access to the EU Single Market has been found to be an important determinant of the location choice of foreign affiliates in Ireland and other EU countries (Davies et al., 2016; 2018). Siedschlag and Tong Koecklin (2019) found that over the period 2003-2015 conditional on location-specific factors such as market size, access to the EU Single Market, labour costs, workforce skills, research and innovation capacity, and corporate taxation - Ireland attracted on average per annum 5.5 per cent of all new greenfield FDI projects going to the EU while Northern Ireland's corresponding share was 0.3 per cent. The attractiveness of Ireland to FDI was higher for FDI by investors from non-EU countries while Northern Ireland was more attractive to FDI by investors from EU countries (including Ireland).

Existing evidence on the location choice of FDI in knowledge-intensive activities such as research and development (R\&D) and information and communication technologies (ICT) industries indicates that the knowledge-base of locations and proximity to other foreign affiliates in high-value sectors are important factors considered by multinational firms. Siedschlag et al. (2013a) provide evidence showing that the availability of high skills, proximity to other R\&D activities by multinationals, the research and innovation capacity of locations and proximity to centres of research excellence are important determinants of the location choice of R\&D activities by multinationals across EU regions. Further, Siedschlag et al. (2013b) find that market size, the innovation intensity of locations and proximity to other foreign affiliates in the ICT industries enhanced the attractiveness of EU regions to FDI in ICT industries.

A study commissioned by the Department of Enterprise, Trade and Investment in Northern Ireland (fDi intelligence, 2012) found that over the period 2006-2010, the share of high-value greenfield FDI in all greenfield FDI projects was 62.8 per cent in Ireland, 56.4 per cent in Northern Ireland and 55.2 per cent in the UK. Over the analysed period, Northern Ireland has been successful in attracting high-value FDI in software development, aerospace and telecommunications, while Ireland has been successful in attracting FDI in financial services, pharmaceuticals and biotechnology.

Examining the potential impact of Brexit on the attractiveness of Northern Ireland to FDI, Siedschlag and Tong Koecklin (2019) found that, in the medium to long term, Northern Ireland would become more attractive to FDI in a situation when Northern Ireland would remain in the EU Customs Union and the Single Market for goods and the rest of the UK would have a free trade agreement with the EU. The 
highest gains for Northern Ireland's attractiveness would be for FDI in manufacturing by non-EU investors.

These research results suggest that Northern Ireland's continued access to the EU Single Market for goods could be an opportunity for greater mutually beneficial cooperation on the island of Ireland including coordination on enterprise policies aimed at enhancing the attractiveness of the island of Ireland to FDI in high-value sectors.

The all-island offering for FDI in key sectors has been highlighted as an opportunity associated with cross-border collaboration on innovation policy in Ireland and Northern Ireland (Nauwelaers et al., 2013). In this context, economies of scale (critical mass) and economies of scope (knowledge complementarities) have been identified as important drivers of cross-border cooperation (OECD, 2013).

Potential benefits of developing sectoral ecosystems on the island of Ireland have been also highlighted by a research study published by InterTradelreland (Morgenroth et al., 2015). Potential opportunities for both Ireland and Northern Ireland have been identified on the basis of an in-depth analysis of three sectors: pharmaceuticals, medical devices and software.

Against this background, this research will examine factors and policies underlying the attractiveness of Ireland and Northern Ireland FDI in high-value sectors such as pharmaceuticals, information and communication technologies (ICT), aerospace, biotechnology and software. The analysis will identify and quantify the importance of a range of location-specific factors and policies including: market size, EU and global market potential, workforce skills, labour costs, R\&D and innovation capacity, public investment in R\&D, corporate taxation, infrastructure, and hightech clusters. Further, a counterfactual analysis will examine possible scenarios for enhancing the attractiveness of the two jurisdictions on the island to high-value FDI in response to a range of policy choices and coordination options available to the Government of Ireland and the Northern Ireland Executive. Potential policy levers to be considered include workforce skills, economic infrastructure, business regulations, public investment in R\&D, and corporate taxation.

\subsection{POLICY CONTEXT AND RELEVANCE OF STUDY TO POLICY}

The results of this research will inform the design of complementary policy steps that might be taken North and South to enhance the attractiveness of the island of Ireland to FDI in key high-value sectors. Such policy analysis will contribute to considerations on the potential for greater cooperation and coordination on enterprise policies on the island of Ireland, which is one of the stated objectives of 
the Shared Island initiative. This research will also link with other policy relevant research strands being undertaken under the Shared Island Research Programme on higher education and skills, research and innovation, infrastructure, and the overall enabling policy environment for enterprise.

Building on the results of this research, further analysis could examine factors and enterprise policies underlying the establishment of new indigenous companies in high-value sectors and cross-border spillover effects from establishment by foreign affiliates on the performance of indigenous companies across the island of Ireland.

A further research strand could focus on factors and policies underlying the attractiveness of border regions North and South to FDI and indigenous companies in high-value sectors including potential cross-border spillovers. On the basis of this evidence, this research would identify opportunities for enhancing cross-border economic integration through models such as Border Economic Zones.

Taken together, the results of this research will inform the design of policies that could enable and foster the diffusion of knowledge and innovation on the island of Ireland and strengthen the productivity and competitiveness of Ireland and Northern Ireland.

\subsection{RESEARCH DESIGN AND METHODS}

This research will first examine and quantify the importance of a range of locationspecific factors and policies underlying the attractiveness of both jurisdictions on the island of Ireland to FDI in high-value sectors including: market size, EU and global market potential, workforce skills, labour costs, R\&D and innovation capacity, public investment in R\&D, corporate taxation, infrastructure, and hightech clusters. Second, these results will be used to identify and analyse possible scenarios for enhancing the attractiveness of the island of Ireland to high-value FDI in response to a range of policy choices available to the Government of Ireland and the Northern Ireland Executive. Potential policy levers to be considered include workforce skills, economic infrastructure, business regulations, public investment in R\&D, and corporate taxation.

This analysis will build on previous research on modelling the location choice of high-value greenfield FDI by Siedschlag et al. (2013a; 2013b) and on previous research on the attractiveness of Ireland, Northern Ireland and EU countries to greenfield FDI (Davies et al., 2016; 2018; 2021; Siedschlag and Tong Koecklin, 2019). 
The analysis will be based on a newly generated dataset including information on new greenfield FDI projects in high-value sectors established on the island of Ireland and across EU regions over the past two decades, ${ }^{11}$ combined with regional statistics from Eurostat.

The research will be structured as follows:

- Data extraction and preparation of dataset;

- Descriptive analysis of the spatial distribution of new greenfield FDI projects in high-value sectors on the island of Ireland and across EU regions;

- Econometric analysis of the importance of location-specific factors and enterprise polices for the attractiveness of the island of Ireland to FDI in highvalue sectors;

- Policy scenarios for enhancing the attractiveness of the island of Ireland to FDI in high-value sectors;

- Summary of key findings and policy implications.

\subsection{EXPECTED CONTRIBUTION TO EVIDENCE BASE}

This research will provide novel evidence on the importance of location-specific factors and enterprise policies that influence the attractiveness of the island of Ireland to FDI in high-value sectors. This evidence will strengthen the knowledge base for policy choices available to the Government of Ireland and the Northern Ireland Executive aiming at enhancing the attractiveness to FDI in high-value sectors, in particular for policies in the areas of workforce skills, economic infrastructure, business regulations, public investment in R\&D, and corporate taxation.

Taken together, the results of this research will contribute to identify cooperation and policy coordination opportunities on the island of Ireland and a potential allisland offering for FDI in key high-value sectors. 


\section{REFERENCES}

Bajgar, M. and B. Javorcik (2020). 'Climbing the Rungs of the Quality Ladder: FDI and Domestic Exporters in Romania', The Economic Journal, 130(628): 937-955. https://doi.org/10.1093/ej/ueaa003.

Bloom, N., C. Genakos, R. Sadun and J. Van Reenen (2012). 'Management Practices across Firms and Countries', Academy of Management Perspectives, 26(1): 12-33. https://doi.org/10.5465/amp.2011.0077.

Ciani, A. and M. Imbruno (2017). 'Microeconomic mechanisms behind export spillovers from FDI: Evidence from Bulgaria', Review of World Economics 153:703-734. https://doi.org/10.1007/s10290-017-0290-4.

Davies, R.B., I. Siedschlag and Z. Studnicka (2016). 'Corporate Taxation and Foreign Direct Investment in EU Countries: Policy Implications for Ireland', Special Article, Quarterly Economic Commentary, The Economic and Social Research Institute, Dublin. www.esri.ie/publications/corporate-taxation-and-foreign-directinvestment-in-eu-countries-policy-implications.

Davies, R.B., I. Siedschlag and Z. Studnicka (2018). 'Corporate Taxation and the Location Choice of Foreign Direct Investment in EU Countries', ESRI W.P. No. 591, Dublin. https://www.esri.ie/system/files/media/file-uploads/2018-03/WP591.pdf.

Davies, R.B., I. Siedschlag and Z. Studnicka (2021). 'The Impact of Taxes on the Extensive and Intensive Margins of FDI', International Tax and Public Finance, 28(2): 434-464. https://doi.org/10.1007/s10797-020-09640-3.

Di Ubaldo, M., M. Lawless and I. Siedschlag (2018). 'Productivity Spillovers from Multinational Activity to Local Firms in Ireland', OECD Productivity Working Paper No. 16, OECD, Paris. https://doi.org/10.1787/58619717-en.

Di Ubaldo, M. and I. Siedschlag (2020). 'Could Spillovers from Multinationals Affect the Trade Activities of Local Firms?', FREIT Working Paper No. 1670, Forum for Research in International Trade. https://www.freit.org//WorkingPapers/Papers/FirmLevelTrade/FREIT1670.pdf.

Driffield, N. and K. Lavoratori (2020). 'Spillovers from Inward investment - A Comparison of Northern Ireland with the rest of the UK', Research Report, Department for the Economy Northern Ireland, Belfast. https://www.economyni.gov.uk/publications/spillovers-inward-investment-comparison-northernireland-rest-uk.

fDi intelligence (2012). 'Improving the Quality of FDI to Northern Ireland', Department for Enterprise, Trade and Investment Northern Ireland, Belfast. https://www.economy-ni.gov.uk/publications/improving-quality-foreign-directinvestment-northern-ireland. 
Fontagné, L. and T. Mayer (2005). 'Determinants of Location Choices by Multinational Firms: A review of the current state of knowledge', Applied Economic Quarterly 51: 9-34.

Havranek, T. and Z. Irsova (2011). 'Estimating Vertical Spillovers from FDI: Why Results Vary and What the True Effect Is', Journal of International Economics, 85: 234-244. https://doi.org/10.1016/j.jinteco.2011.07.004.

Jude, C. (2016). 'Technology Spillovers from FDI: Evidence on the Intensity of Different Spillover Channels', The World Economy, 39(12): 1947-1973. https://doi.org/10.1111/twec.12335.

Lawless, M., D. McCoy, E. Morgenroth and C. O'Toole (2018). 'Corporate Tax and Location Choice for Multinational Firms', Applied Economics, 50(26): 2920-2931. https://doi.org/10.1080/00036846.2017.1412078.

Morgenroth, E., C. van Egeraat, D. Curran, N. Hewitt-Dundas, R. Kroes and J. Gleeson (2015). Mapping the Potential for All-Island Sectoral Ecosystems, InterTradelreland. www.esri.ie/publications/mapping-the-potential-for-allisland-sectoral-ecosystems-a-summary-report.

Nauwelaers, C., K. Maguire and G. Ajmone Marsan (2013). 'The case of Ireland-Northern Ireland (United Kingdom) - Regions and innovation: Collaborating across borders', OECD Regional Development Working Papers, 2013/20, OECD Publishing. https://doi.org/10.1787/5k3xv0llxhmr-en.

OECD (2013). Regions and Innovation: Collaborating across Borders, OECD Reviews of Regional Innovation, OECD Publishing. https://doi.org/10.1787/9789264205307en.

Schiffbauer, M., I. Siedschlag and F. Ruane (2017). 'Do Foreign Mergers and Acquisitions Boost Firm Productivity?', International Business Review, 26(6): 1124-1140. https://doi.org/10.1016/j.ibusrev.2017.04.003.

Siedschlag, I., D. Smith, C. Turcu and X. Zhang (2013a). 'What Determines the Location Choice of RandD Activities by Multinational Firms?', Research Policy, 42(8): 1420-1430. http://dx.doi.org/10.1016/j.respol.2013.06.003.

Siedschlag, I., X. Zhang and D. Smith (2013b). 'What Determines the Location Choice of Multinational Firms in the Information and Communication Technologies Sector?', Economics of Innovation and New Technology, 22(6): 581-600. https://doi.org/10.1080/10438599.2013.783266.

Siedschlag, I. and M. Tong Koecklin (2019). 'The Impact of EU Exit on the Attractiveness of FDI to Northern Ireland and Associated Job Creation Effects', Research Study, Department for the Economy Northern Ireland, Belfast. https://www.esri.ie/system/files/publications/BKMNEXT379_NI.pdf. 
Whitaker Square,

Sir John Rogerson's Quay,

Dublin 2

Telephone +35318632000

Email admin@esri.ie

Web www.esri.ie

Twitter @ESRIDublin 